\title{
CALIBRATION OF BORROWER-BASED \\ MACROPRUDENTIAL MEASURES FOR MORTGAGE EXPOSURES: RIGOROUS APPROACH AND ITS APPLICATION TO THE CZECH REPUBLIC*
}

\author{
Hana Hejlováa,b (iD, Libor Holubb (D), Miroslav Plašil ${ }^{c, b}$
}

\begin{abstract}
Although the use of residential real estate macroprudential tools has become common in recent years, rigorous approaches to their calibration have been relatively scarce. The goal of this paper is to present an approach to (i) evaluating direct risks to financial stability related to residential real estate exposures, and to (ii) calibrating borrower-based macroprudential measures. First we present a macroprudential indicator of potential losses related to the provision of new mortgage loans. Then we show how to determine risky values of the loan-to-value, loan-to-income and loan service-to-income ratios by performing stress tests on the individual new mortgage loans. Finally, we demonstrate the applicability of this approach on the case of the Czech Republic. We conclude by showing that simultaneous adoption of several macroprudential measures may enhance their efficiency without imposing higher restrictions on the mortgage market.
\end{abstract}

Keywords: Macroprudential policy, borrower-based measures, calibration JEL Classification: E32, E58, G21, R21, R31

\section{Introduction}

Risks to financial stability usually build up in an upward phase of the financial cycle (henceforth referred to as "good times") characterized by overvalued house prices, relaxed credit standards and rapid growth in loans secured by residential property (henceforth

\footnotetext{
* The views expressed are those of the authors and do not necessarily reflect the views of the institutions that the authors are affiliated to. This research was supported by the Czech Science Foundation (Project No. GA 18-05244S). The work draws on Hejlová, Holub, Plašil (2018): Introduction and Calibration of Macroprudential Tools Targeted at Residential Real Estate Exposures in the Czech Republic, Financial Stability Report 2017/2018, Czech National Bank, pp. 126-135.

a Charles University, Prague, Czech Republic

b Czech National Bank, Prague, Czech Republic

c Prague University of Economics and Business, Prague, Czech Republic

Email: hana.hejlova@fsv.cuni.cz
} 
also referred to as "loans" or "mortgage loans") (Cerutti et al., 2015). These conditions increase risks to the financial sector, which can later face considerable credit losses during downturn of the financial cycle (henceforth referred to as "bad times"). If the losses reach a systemic scale, they may potentially result in a financial crisis. Given their mandate, national macroprudential authorities have to respond to systemic risk build-up in a timely manner by deploying macroprudential policy tools.

For the EU countries, some of the macroprudential tools are set out in Capital Requirements Regulation and Capital Requirements Directive (CRR/CRD), which primarily covers capital requirements and capital buffers. Other tools, commonly referred to as borrower-based measures, are defined in a recommendation of the European Systemic Risk Board (ESRB) $)^{1}$ but their availability in a legally binding form depends on national legislations. These include limits for loan-to-value (LTV), loan-to-income/debt-to-income (LTI/DTI) and loan service-to-income/debt service-to-income (LSTI/DSTI) ratios.

Although LTV, LTI/DTI and LSTI/DSTI caps are commonly used in EU countries, their rigorous calibration is quite rare (Thedéen, 2018). In most countries, there was no ex-ante assessment of the measures at the time of their introduction and the calibration of the tools was largely discretionary in many of them (Jacome and Mitra, 2015). This is mostly due to a lack of necessary data on new loans, as well as measurement issues. The use of these measures has been quite novel, offering a short time span of data for analysis, and they have often been implemented in combination or complemented with measures from other policy areas (Dell'Ariccia et al., 2012). While the Financial Policy Committee of the Bank of England provides a set of indicators which they consider for recalibration of the measures, they warn that no indicators should be used mechanically and they emphasize the need for policy judgement (FPC, 2015). As such, calibration of these tools will be a learning process, similar to that of monetary policy in the past (Dell'Ariccia et al., 2011).

Regarding the use of debt- versus loan-related instruments, the general assumption is that the use of the DTI and DSTI limits is more efficient than that of the LTI and LSTI because it prevents circumvention of the limits by concurrent provision of other loans. Calibration of the DTI and DSTI limits is, however, again hindered by low data availability. In many countries and especially those in which there is no credit register for physical persons, the information on the overall debt of individuals who have taken new loans may be missing or it may not be available for a sufficiently long period.

1 ESRB Recommendation on intermediate objectives and instruments of macro-prudential policy (ESRB/2013/1). 
In this article, we propose a rigorous approach to (i) measuring direct risks to financial stability related to residential real estate exposures and (ii) calibrating borrower-based macroprudential measures. Finally, we apply this approach to the case of the Czech Republic. To this end, we use anonymized survey-based data on new loans that have been collected by the Czech National Bank (CNB) since the second half of 2015, as sound quantification of macroprudential tools requires granular data. (IMF, 2018). These data are loan-level and allow us to determine the risky levels of the LTI and LSTI ratios. For this reason, we complement our analysis with a discussion on why DSTI and DTI value for one borrower can be usually considered equally or more risky than the same LSTI and LTI value for another borrower with similar income characteristics.

This article is above all a policy paper, building on existing best practices in the international literature and usable in practical macroprudential policymaking. However, we believe that the systemic and quantitative nature of the approach, which we use to measure the risks and calibrate the macroprudential measures, represents a clear value added and makes it different from other papers on the same topic. Even though we provide an ad hoc application of the approach to the example of the Czech Republic, the approach is more general and may be used in other countries as well after specific adjustments.

The article is organized as follows. Section 2 provides a concise review of systemic risks to financial stability associated with the residential real estate sector. Section 3 describes the set of available macroprudential tools that can be used to mitigate them. Section 4 provides a framework for evaluation of the residential real estate risks and calibration of the borrower-based macroprudential measures. Section 5 makes an application of the proposed approach to the Czech Republic and Section 6 concludes.

\section{Risks Associated with Residential Real Estate Exposures}

There are three main risk areas commonly considered in the current international practice. Namely, it might be useful to separately assess risks related to (i) collateral value, i.e., property prices, (ii) consumers' income and debt servicing capacity and (iii) institutions' loan portfolios and capitalisation (see ESRB, 2016, and Table 1).

Ad (i): The dominant type of collateral used for mortgage loans is residential property, which is usually also financed with the loan. The risks of collateral insufficiency can arise in a situation in which house prices increase above the level warranted by fundamentals (and become "overvalued") and these developments are not fully recognized by the lenders. ${ }^{2}$ This increases the potential loss given default in the event of a subsequent slump in house prices to, or below, their equilibrium level. The unaltered LTV ratios amid more overvalued

2 See, for example, Box 5.1 Assessment of property price valuation by banks in CNB (2018). 
house prices imply greater risks to lenders (other things equal). House prices tend to be overvalued in good times, which are associated with growth in income and lending and relaxed credit conditions. This fuels growth in demand for housing, which tends to face less elastic supply. A major factor driving the growth in demand is overly optimistic expectations of households about further rise in house prices and interest rates, which in turn can motivate them to rush into property investment. This creates self-reinforcing loops between house prices and mortgage lending (FPC, 2015). Risks can materialize in bad times when nonperforming loans (NPLs) start to increase. In this situation, a fall in property prices can give rise to credit losses when the property serving as collateral for such loans is sold.

$\mathrm{Ad}$ (ii): Income tends to be the main source of own funds used to repay mortgage loans. Given the length of mortgage repayment terms and the possibility of loss of employment or other sources of income, borrowers' debt servicing capacity hinges on the sustainability of their income. A risk can arise if households accumulate excessive debt, as this increases the probability of default in bad times. Risks can materialize in the event of losses of, or declines in, borrowers' income, or an increase in interest rates. In such a situation, debt service costs can exceed income net of necessary expenditure, leading to default. If house prices fall simultaneously, credit losses can occur as described above and amplify stress. In addition, growth in household debt can lead to a decrease in consumption and indirectly put financial stability at risk, for instance through credit losses on loans to non-financial corporations. Such losses can result from economic difficulties caused by firms cutting production or service provision in response to the fall in household consumption.

Ad (iii): Lenders' credit portfolios are made up of loans with certain risk characteristics, which together tend to form a large part of their credit standards. Lenders use these characteristics as a basis for determining the risk component of the interest rate, which is largely a function of risk. This interest rate is meant to cover not only the expected losses on those loans, but also the costs of the capital held to cover unexpected losses (along with other components such as liquidity costs). A risk can arise in situations where loan rates and the capital held by lenders do not take into account the risks associated with collateral value (i) and consumers' income and debt servicing capacity (ii). Relaxation of credit standards is particularly common in good times, driven by optimistic expectations and increased competition on the credit market. Risks can materialize in the event of a sharp increase in NPLs accompanied by a fall in house prices. In such a situation, credit losses can reduce capital below the regulatory minimum, leading to a credit crunch in the real economy and even to a need to apply resolution mechanisms in the banking system.

The first two categories of risks are referred to jointly as borrower-related (see Table 1) and can lead to the emergence of spirals between house prices and house purchase loans. 
In such a case, house price overvaluation and credit growth gradually reinforce each another. The third category of risks is referred to as lender-related. Such risks arise when the potential loan losses are not adequately balanced by lender resilience.

\section{Macroprudential Tools for Mitigating Risks Associated with Residential Real Estate Exposures}

Tools can be used to mitigate both borrower- and lender-related risks. The tools that target lenders are aimed at increasing the resilience of lenders during bad times and therefore influence the amount of capital they hold. They can work directly through the setting of higher capital requirements on the basis of a whole range of factors, including risks associated with real estate exposures. Such instruments include the countercyclical capital buffer and the systemic risk buffer. Others can work indirectly through variables that affect capital requirements connected with exposures secured by residential property. They include higher risk weights for banks using the standardized approach to determine capital requirements for credit risk (under Article 124 of the CRR), a higher loss given default for banks using the internal rating based approach (under Article 164 of the CRR) and temporarily higher risk weights in the residential or commercial property sector (under Article 458 of the CRR). These tools increase the amount of capital held by banks in relation to their risk-weighted exposures, enabling them to better absorb unexpected losses on existing loans secured by residential property. A side-effect is that they can again prevent the emergence of spirals as a result of the higher capital requirements passing through to interest rates, and thereby contain or slow economic growth.

The tools that target borrower-related risks directly restrict the volume of credit provided in relation to its riskiness (Dell'Ariccia et al., 2012). Macroprudential authorities in numerous countries set LTV limits, which are aimed at reducing lenders' losses given default by borrowers and a simultaneous fall in house prices, and LTI/DTI or LSTI/DSTI limits, which are targeted at reducing the probability of default by borrowers during an economic downturn (ESRB, 2014). The use of these measures differs across countries, including the primary objective to either curb the financial cycle in a precautionary way or to enhance resilience (Cassidy and Hallissey, 2016). While these measures leave marginal borrowers out of lending (Dell'Ariccia et al., 2012), in the short run they affect the quantity and distribution of mortgage lending and the expectations of market participants (FPC, 2015). All of these instruments also rein the purchasing power of households, reducing the pressure on house prices and thus decreasing the systemic risks (Dell'Ariccia et al., 2011). When used in a timely fashion, they may therefore help to prevent the emergence of spirals between house price growth and house purchase loans. 
Table 1: Overview of risks to financial stability associated with exposures secured by residential property

\begin{tabular}{|c|c|c|c|c|c|}
\hline \multirow[t]{2}{*}{$\begin{array}{l}\text { Breakdown } \\
\text { of risks }\end{array}$} & $\begin{array}{c}\text { Risks associated } \\
\text { with collateral value/ } \\
\text { house prices }\end{array}$ & \multicolumn{2}{|c|}{$\begin{array}{l}\text { Risks associated } \\
\text { with borrowers' debt } \\
\text { servicing capacity }\end{array}$} & \multirow{2}{*}{\multicolumn{2}{|c|}{$\begin{array}{c}\begin{array}{c}\text { Risks associated } \\
\text { with lenders' } \\
\text { capitalisation }\end{array} \\
\text { Lender-related risks }\end{array}$}} \\
\hline & \multicolumn{3}{|c|}{ Borrower-related risks } & & \\
\hline \multirow{2}{*}{$\begin{array}{l}\text { Sources } \\
\text { of risks }\end{array}$} & \multicolumn{2}{|l|}{ Direct } & Indirect & Direct & Indirect \\
\hline & $\begin{array}{l}\text { house price overvaluation } \\
\text { potential fall in house prices } \\
\text { method for determining } \\
\text { collateral value }\end{array}$ & \multicolumn{2}{|c|}{$\begin{array}{l}\text { excessive household debt } \\
\text { potential loss of, or fall in, income } \\
\text { and rise in interest rates }\end{array}$} & \multicolumn{2}{|c|}{$\begin{array}{l}\text { undercapitalisation } \\
\text { relative to risks associated with } \\
\text { house prices and debt servicing } \\
\text { capacity }\end{array}$} \\
\hline $\begin{array}{l}\text { Ways } \\
\text { the risks } \\
\text { materialise }\end{array}$ & $\begin{array}{c}\uparrow \text { mortgage defaults } \\
\downarrow \text { house prices }\end{array}$ & \multicolumn{2}{|c|}{$\begin{array}{c}\downarrow \text { income } \\
\uparrow \text { unemployment } \\
\uparrow \text { interest rates }\end{array}$} & $\begin{array}{c}\uparrow \text { losses } \\
\text { on mortgages }\end{array}$ & \begin{tabular}{l}
$\uparrow$ losses \\
on other loans \\
\} \\
\hline $\begin{array}{l}\text { Impacts } \\
\text { of risk } \\
\text { materialising }\end{array}$ & $\begin{array}{r}\uparrow \text { losses on mortgages } \\
\text { of which: } \uparrow \text { default rate } \\
\uparrow \text { loss given default }\end{array}$ & \multicolumn{2}{|c|}{$\begin{array}{l}\downarrow \text { household consumption } \\
\uparrow \text { credit losses, e.g., } \\
\text { on loans to NFCs }\end{array}$} & \multicolumn{2}{|c|}{$\begin{array}{l}\downarrow \text { lending constraints } \\
\text { application of resolution } \\
\text { mechanisms }\end{array}$} \\
\hline $\begin{array}{l}\text { Risk } \\
\text { mitigation } \\
\text { tools }\end{array}$ & LTV limits & \multicolumn{2}{|c|}{ LTI/DTI, LSTI/DSTI limits } & \multicolumn{2}{|c|}{$\begin{array}{l}\text { countercyclical capital buffer } \\
\text { systemic risk buffer } \\
\text { increase in risk weights } \\
\text { minimum LGD }\end{array}$} \\
\hline
\end{tabular}
\end{tabular}

Note: Arrows indicate links between the ways in which risks materialise and the impacts of them materialising. Defaults can occur in a situation of excessive household indebtedness coupled with a decline in income, a rise in unemployment or an increase in interest rates. This can lead to a decrease in household consumption and to credit losses, for example on loans to non-financial corporations (risks associated with borrowers' debt servicing capacity). If defaults are accompanied by a decline in house prices, losses on mortgages can occur (risks associated with house prices). Losses on mortgages or, for example, loans to non-financial corporations can exceed the funds that lenders have available to cover such losses (risks associated with lenders' capitalisation). "NFCs" stands for non-financial corporations and "LGD" for loss-given default.

Source: Authors based on ESRB (2016)

The limits are applied to new loans and they may be defined either as hard caps or as soft limits allowing a percentage of loans to be provided in excess of the limit. In such cases, the proportionate caps reflect the fact that in some circumstances lending with higher LTVs or LTIs might be appropriate, while leaving the responsibility for the individual exemptions with the banks (Cassidy and Hallissey, 2016). The limits may also be differentiated depending for example on the type of borrower (Cassidy and Hallissey, 2016), currency of the loan or the level of disposable income of the loan applicants (Fáykiss et al., 2018). However, careful design which limits the space for circumvention is key to the effectiveness of these measures (Dell'Ariccia et al., 2011). While the measures have potential to address the risks in a very targeted way, such use may lead to a shift of risks to less or non-regulated 
parts of the financial system or to riskier products (Dell'Ariccia et al., 2016). For this reason, the borrower-based measures should be used in a broad-based way (Upper, 2017). Leakages should be avoided, for example, by targeting the overall indebtedness of borrowers and by applying the measures to all institutions that provide mortgage loans. A number of studies favour complementing the LTV limits with limits to income-related ratios to ensure efficiency of the policy mix (see, for example, Cassidy and Hallissey, 2016).

The use of the above instruments is contingent on the observed risk levels and dynamics. As a preventive measure (when risks are rising but still not elevated), it can be particularly suitable to use tools that target borrowers (Riksbank, 2012). As they directly restrict the provision of new loans with riskier characteristics, they may work more effectively against build-up of risks. When the risks are already elevated, it can be more appropriate to deploy instruments that strengthen lenders' capitalization. In practice, O'Brien and Ryan (2017) find out that many EU countries have used borrower-based and capital-based measures, especially the positive counter cyclical capital buffer, in conjunction.

In the remainder of this article, we will concentrate on borrower-related risks and calibration of borrower-based measures. Specifically, we will consider the situation where there are risks associated with collateral value and at the same time risks associated with borrowers' income and debt servicing capacity. Furthermore, we will focus on direct risks associated with exposures secured by residential property and abstract from the indirect risk of a threat to financial stability resulting from a sharp fall in household consumption caused by household over-indebtedness (Table 1).

\section{Proposed Approach to Evaluating Residential Real Estate Risks and Calibrating Borrower-based Macroprudential Measures}

\subsection{Evaluating residential real estate risks}

We propose to evaluate the direct risks stemming from residential real estate exposures as a function of three variables: house price overvaluation, credit standards and credit volume (Equation 1). House price overvaluation and credit standards together determine the potential losses on the average unit volume of credit and hence are indicators of the riskiness of loans. Combined with the volume of credit, they indicate the total potential losses on those loans and are thus indicators of the total size of the risks associated with such loans. To identify the risks in a timely manner, these variables can be related to new loans:

$$
\text { risks }=\mathrm{f}(\text { price overvaluation, } \text { credit standards, credit volume) }
$$


For evaluation purposes, the key quantitative measures of credit standards are the LTV, which, together with house price overvaluation, determines the loss given default (LGD), the ratio of loans with excessive debt service or loan size relative to the characteristics of the borrowers (the ratio of loans at risk of default under stress), which indicate the probability of default (PD), and the volume of newly provided loans:

$$
M I P L=\frac{\sum_{\mathrm{i}} \text { loan size }_{\mathrm{i}}}{\text { new credit volume }} \times \sum_{\mathrm{i}} \min \left[\left(100 \%-L T V_{i}\right)-\text { overvaluation } ; 0\right] \times
$$

$\times$ new credit volume

where MIPL denotes the macroprudential indicator of potential losses on new loans, $i$ denotes individual loans with at risk of default under stress, $(100 \%-L T V)$ denotes the share of over/ under-collateralisation by property, $(100 \%-L T V)$ - overvaluation denotes the proceeds from the sale of the collateral given a fall in house prices and $\min [(100 \%-$ LTV $)$-overvaluation; 0$]$ restricts the proceeds to negative values or zero, i.e., to credit losses. ${ }^{3}$

Some simple examples can be given to facilitate a better understanding of Equation (2). If the LTV is $80 \%$, the over-collateralisation is $20 \%$ and there will be no loss on the sale of the collateral if house prices fall by $15 \%(\min [(100 \%-80 \%)-15 \% ; 0]=0) .{ }^{4}$ However, if house prices fell by $25 \%$, the loss on the sale of the collateral would equal $5 \%$ of the credit volume $(\min [(100 \%-80 \%)-25 \% ; 0]=-5 \%){ }^{5}$ If the LTV was $110 \%$, the undercollateralisation would equal $10 \%$ and a drop in house prices of $15 \%$ would give rise to a loss on the sale of the collateral of $25 \%$ of the credit volume $(\min [(100 \%-110 \%)-15 \% ; 0]=-25 \%)$. House price overvaluation can be estimated using various techniques developed by the national macroprudential authorities. ${ }^{6}$ Loans at risk of default under stress can be determined according to the approach described in sections 4.2.1 and 4.2.2 of this article, i.e., as individual loans for which the financial reserve under stress is lower than the set threshold or for which the loan size is higher than the hypothetical repayable loan under stress.

The MIPL should not be considered an exact estimate of credit losses on new loans in the event of stress. Rather, it should be taken as an indicator of such losses

3 While the new credit volume, which stands for the volume of newly provided loans, could be eliminated from Equation (2), it is useful to keep it in for explanatory purposes. In particular, it shows how the MIPL can be broken down into the indicator of PD, LGD and matrices of volume. As we will show further, such a breakdown is important for the calibration of individual macroprudential instruments. In practice, however, the MIPL can be calculated simply as a sum of potential losses on individual loans which are identified at risk of default under stress.

4 We abstract from transaction costs arising from the sale of the property and the termination of the credit relationship.

5 In this example, we abstract from the fact that the loan may have been partially repaid.

6 See, for example, Plašil and Andrle (2019) or Schneider (2013). 
for macroprudential purposes, one which uses certain prudent assumptions to express those losses. The loss given default can be favourably affected by lenders' ability to put the sale of collateral on hold until house prices start to go up again. ${ }^{7}$ It can be adversely affected by the actual situation on the property market and by its duration in the event of a significant price correction of a systemic nature following a long period of growth above the equilibrium level. Nonetheless, a rise in the MIPL over time indicates growth in risks, to which it may be appropriate to respond with macroprudential policy. The evolution of the components of this indicator (the share of loans with possibility of default under stress and the LGD) can meanwhile help determine which macroprudential instrument to use. A fall in the MIPL following the introduction of macroprudential instruments can then indicate the degree of effectiveness of the instruments.

\subsection{Calibrating borrower-based macroprudential measures}

We define a proper calibration of the borrower-based measures as such that restricts the provision of loans with LTV, DSTI and DTI levels that could otherwise lead to credit losses not being absorbed by lenders' capital. However, the potential losses that would be generated by a sustained spiral between house prices and house purchase loans are hard to estimate. For this reason, we propose to determine the risky levels of the LTV, DSTI and DTI on a relative basis. Such an approach involves seeking the thresholds at which the risk of default or the loss rate starts to increase substantially. A similar approach was adopted in IMF (2018). For the LTV ratio, it holds that higher LTV levels (i.e., lower collateralization) almost always imply a higher loss given default. For the DSTI and DTI ratios, however, the probability of default depends on a whole range of factors, such as the borrower's income and age, the nature of the household and the probability of loss of income.

\subsubsection{LTV limits}

If risks associated with collateral value are identified, the primary tool used to mitigate them is the LTV limit, which represents a requirement for over-collateralization ${ }^{8}$ and thus allows direct or preventive restriction of credit losses in the event of default and a decline in house prices. In most of the EU countries, the collateral value is determined as an estimate of the market price of the property and can thus contain the cyclical component of such

7 This ability is given by lenders' capitalisation.

8 Over-collateralisation relates to the collateral value, which, under the present regulations, can be determined as the estimated market value of the real estate used as collateral. Depending on the degree of overvaluation of house prices, a loan may also be under-collateralised with respect to the equilibrium value of the collateral. 
prices. ${ }^{9}$ To determine risky LTV levels, we therefore propose to monitor the estimated overvaluation of house prices. The degree of over-collateralization needed to restrict the credit losses given default and given a decline in house prices is equal to $(100 \%-L T V)$. The risky LTV levels $\left(L T V_{R}\right)$ are thus given by:

$$
L T V_{R} \geq 100 \% \text {-overvaluation }
$$

In this way, the LTV values after the house price decline, which is equal to the overvaluation of house prices as estimated at the given moment, would always be equal to $100 \%$ as maximum (similar to Geršl, 2016). When the LTV limits are used as a cyclical instrument, they can be tightened or eased in a way that mirrors the dynamics of the estimated overvaluation of house prices.

\subsubsection{DSTI limits}

LSTI/DSTI caps can reduce the probability of borrowers being unable to service loans continuously in accordance with their chosen repayment schedule. To determine risky DSTI levels, we propose to use the concept of the financial reserve under stress $(F R$ ):

$$
\begin{aligned}
& F R_{s}=\text { net income }_{\mathrm{S}}-\text { other necessary costs }- \text { loan repayments } \mathrm{S}_{\mathrm{S}}- \\
& \text { - property maintenance costs }
\end{aligned}
$$

Similar to the approach adopted in Slovakia (NBS, 2016) or Sweden (Finansinspektionen, 2017) this reserve denotes the consumer's net income minus the subsistence level costs, loan repayments and property maintenance costs under the simulated stress (the variables in Equation (4) subject to the stress are indicated by the subscript "s"). In the context of the survey data on new loans provided in the Czech Republic, subsistence costs can be based on the values set by the Ministry of Labour and Social Affairs of the Czech Republic for the first and the other persons in the household and take into account the number of borrowers and their dependents for loans reported in the survey. The true repayments of these loans are used as the loan repayments. Property maintenance costs are set at $1.5 \%$ of the collateral on these loans per year. The stress may consist in a $10 \%$ decrease in income - expressing the probability of loss of employment or a drop in income for a certain period of time - and a steady rise in interest rates of $0.6 \mathrm{pp}$ a year for five years (i.e., a cumulative increase of $3 \mathrm{pp}$ ). The impact of the interest rate stress should respect the fixation and repayment periods of the individual loans reported in the survey. Thus, if the loan has a fixation period of five years, the interest rate increase

9 See Articles 124(1) and 229(1) of the CRR. 
will happen all at once in the fifth year and will affect subsequent instalments only up to the amount of the unrepaid part of the principal. If such a loan has a maturity of five years, the rise in interest rates will not affect it at all.

As individual loans with excessive debt service, we suggest to consider those for which $F R_{S}$ levels are lower than the financial reserve threshold $\left(F R_{T H}\right)$. This should be defined as both a percentage over net income and a minimum absolute value. The requirement for a minimum absolute $F R_{S}$ serves to cover sudden necessary expenditures, which to some extent are independent of income level. As risky DSTI levels, we suggest to consider those for which the share of individual loans with excessive debt service significantly increases. This test should be conducted regularly on a sample of newly provided loans to capture the potential moves in the riskiness of the individual DSTI levels.

\subsubsection{DTI limits}

LTI/DTI caps can lower the probability of them failing to repay loans in full over their remaining period of economic activity (i.e., even after the loan has been restructured and the repayment schedule changed). LTI/DTI caps may also be appropriate when the constraints created by the LSTI/DSTI cap are softened by a lengthening of the repayment term or by low interest rates. As LTI/DTI caps do not work with components that can give the impression of a sustainable level of debt service in the short term (LSTI/DSTI), they can slow the pace at which consumers become over-indebted in real terms. To determine risky DTI levels, we propose to use the concept of the hypothetically repayable loan under stress $\left(H R L_{S}\right)$ :

$$
\begin{aligned}
& H R L_{S}=\left(1-F R_{T H}\right) \times\left(\text { income }_{\mathrm{S}}-\text { property mainteneace costs }-\right. \\
& - \text { other necessary costs }) \times \text { max. maturity }
\end{aligned}
$$

$H R L_{S}$ represents the biggest loan volume the consumer would be able to service over the longest possible maturity if her monthly repayments were at the maximum possible level. After paying such instalments, the consumer would be left at the financial reserve threshold $\left(F R_{S}=F R_{T H}\right)$. As the longest possible maturity, we suggest to consider the consumer's remaining period of economic activity up to the age of 65 , or 30 years, whichever is shorter. A similar approach was used in the Netherlands (IMF, 2018).

The $H R L_{S}$ of individual consumers are compared with the size of the loans actually provided to them. As individual loans of excessive size, we suggest to consider those that are larger than those which consumers would, under stress, be able to service over their period of economic activity ( $L>H R L_{S}$ or also $L / H R L_{S}>100 \%$ ). As risky DTI levels, we suggest to consider those for which the share of individual loans with excessive debt 
service significantly increases. This test should be conducted regularly on a sample of newly provided loans to capture the potential moves in the riskiness of the individual DTI levels.

\subsection{Using a combination of borrower-based measures}

As can be seen from Equation (5), determining risky DTI values is - under our approach quantitatively equivalent to determining risky values of DSTI when considering maximum maturity of the loans that can be seen as prudent. The reason is that the DSTI limits are regulatory maximum instalments in relation to income. In this way, the determination of risky DTI levels using findings about risky DSTI levels guarantees that the resulting risky DTI values implicitly take into account the level of interest rates and the possibility of rates increasing, even though the DTI ratio itself does not contain this information directly.

Further, as can be seen from Equation (1), combining LTV and LTI/DTI or LSTI/DSTI limits restricts the volume of loans that have high PD and LGD levels simultaneously. Moreover, if the caps are defined as soft limits, the introduction of LTI/DTI or LSTI/DSTI caps may not necessarily lead to any significant additional restriction on the total volume of new loans above that given by the LTV limits, because lenders will probably decide initially to restrict those loans which exceed the caps on all the ratios simultaneously, thereby minimizing the impacts of the additional measures.

\section{Application of the Proposed Approach to the Case of the Czech Republic}

We demonstrate the applicability of our approach on the case of the Czech Republic, using anonymized survey-based data on new loans collected by the Czech National Bank since the second half of 2015. The survey data contain the information needed to calculate the LTV, LTI and LSTI ratios as well as the demographic, social and geographical information that enables us to evaluate the riskiness of the individual loans with given LTV, LTI and LSTI values. However, the survey data only convey information on new loans, not on the total debt of applicants for such loans. For this reason, only the data on the LSTI and LTI ratio can be used to determine the risky levels according to sections 4.2.2 and 4.2.3.

In practice, a DSTI and DTI value for one borrower can usually be considered equally or more risky than the same LSTI and LTI value for another borrower with similar income characteristics. This is because the total debt, from which the DTI ratio is calculated, may contain unsecured loans in place of a proportion of secured ones. Unsecured loans typically have higher interest rates and shorter repayment terms than 
secured ones, so that the total debt can imply higher debt service for a borrower than a secured loan of the same amount. Higher debt service in turn implies a higher risk of default at the same level of borrower income. We therefore propose to consider the risky DSTI and DTI levels equal to or lower than those determined on the basis of LSTI and LTI data.

\section{Figure 1: Macroprudential indicator of potential losses (MIPL) on new loans (Part a) and its components (Parts b-d)}

$(2016=100)$

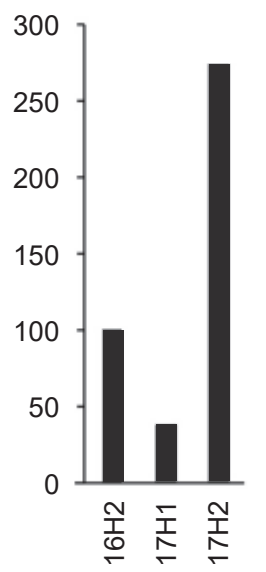

Potential losses (MIPL)

(a)
(\%)

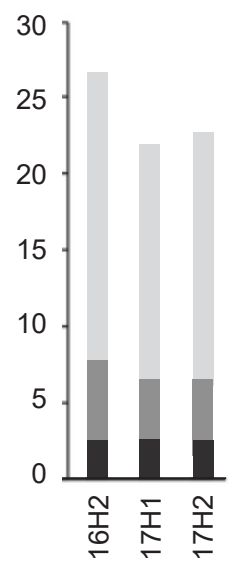

Share of loans at risk of default

(b)

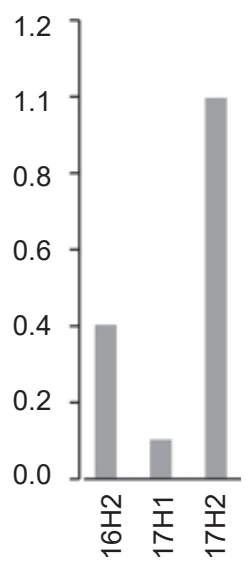

Average LGD of such loans

(c)

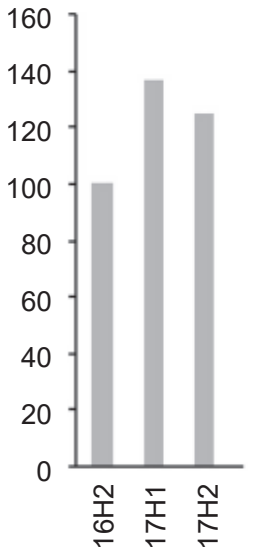

Volume of loans provided

(d)

Of (b) Default associated with debt service and loan size (or LSTI and LTI)

- Of (b) Default associated with loan size (or LTI)

- Of (b) Default associated with debt service (or LSTI)

Note: Figure 1 shows the macroprudential indicator of potential losses on new loans (MIPL, Part (a) of the figure), which is the volume of potential losses on new loans, indexed to the value as of 2016 for which the first data is available. The figure also shows the breakdown of MIPL into three multiplicative components. The first component (Part (b) of the figure) is the share of new loans, which are identified at risk of default using the criteria described in Part 4.2.2 and Part 4.2.3 of this article. The second component (Part (c) of the figure) is the weighted average loss on new loans, which are identified at risk of default. The third component (Part (d) of the figure) is the total volume of loans which were newly provided.

Source: Czech National Bank data, authors' calculations 
Figure 1 displays the results of the $M I P L$ when using the survey data on new loans provided from the second half of 2016 to the second half of 2017 . In the second half of 2017, the indicator rose slightly compared with previous rounds of the survey. This is due mainly to a rising estimate of the average LGD, which reflects increasing overvaluation of house prices in relation to the LTV limits that were in effect and were tightened during the sample period. However, the component of the indicator that assesses the risks associated with borrowers' loan servicing capacity also rose moderately. Conversely, a slight decline in the total volume of new loans reduced the growth in absolute potential losses for the banking sector.

\section{Figure 2: Difference between growth in apartment prices and incomes and possible calibration of an LTV limit (overvaluation in \%; rhs: LTV in \%)}

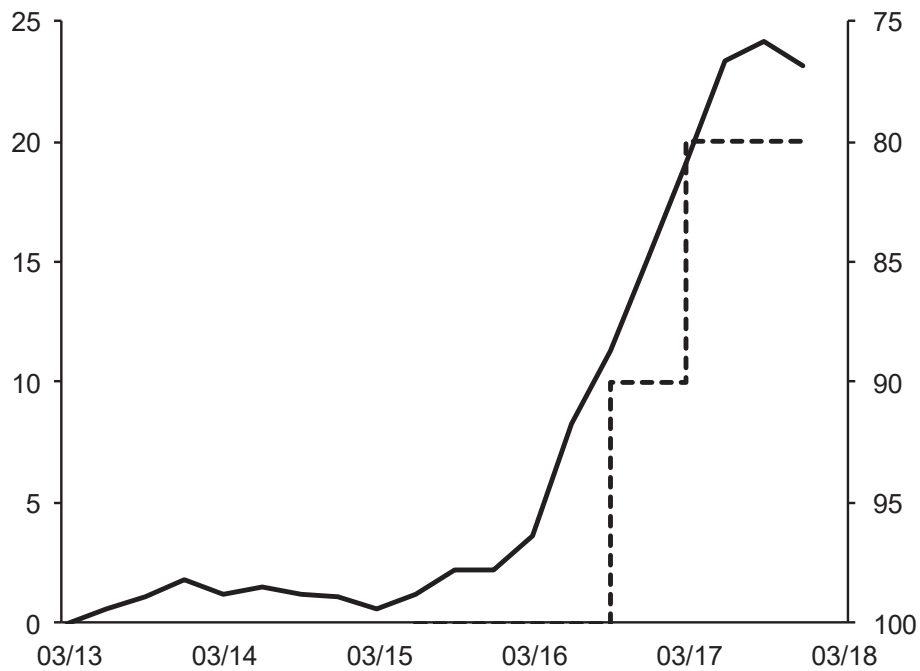

\footnotetext{
- Apartment price overvaluation

- - - Possible calibration of an LTV limit (rhs)
}

Note: Difference between growth in apartment prices and incomes since 2013 Q1, when apartment prices last hit a low. This indicator of apartment price overvaluation assumes that prices were at equilibrium at the low point. This is a cautious assumption, because prices might have been undervalued at that point and hence may not reverse their entire growth in the event of stress. The grey areas indicate, respectively, the phases of the entry into force and tightening of the recommended LTV limits in the CNB's June 2015 and June 2016 Recommendation on the management of risks associated with the provision of retail loans secured by residential property.

Source: Czech Statistical Office data, authors' calculations 
Figure 2 displays the possible calibration of the LTV limit given potential overvaluation of house prices. For simplicity, we use a simple indicator of the house price overvaluation, which takes the difference between the cumulative growth in house prices from the last cyclical trough and the cumulative growth in income over the same period. Such a simple approach assumes that at the cyclical through the house prices are roughly at their equilibrium values and that the growth in house prices which is higher than the growth in income is unsustainable in the medium term. In reality, the house prices may be undervalued at the through and thus the actual overvaluation may be lower, as estimated, for example, by Plašil and Andrle (2019). Using this indicator, the potential overvaluation of house prices ranges between 0 and $22 \%$ from the first quarter of 2013 to the fourth quarter of 2017, suggesting that an LTV limit from around $100 \%$ to $80 \%$ could be introduced with a gradual phasing-in during this period as illustrated, for example, in Figure 2. In practice, the actual calibration may depend on circumstances on the market and design of the measures as mentioned in Section 3.

\section{Figure 3: Distribution of loans by LSTI and financial reserve under stress}

(x-axis: LSTI in \%; y-axis: share of loans in \%; reserve in \% of net income; 2017 H2)

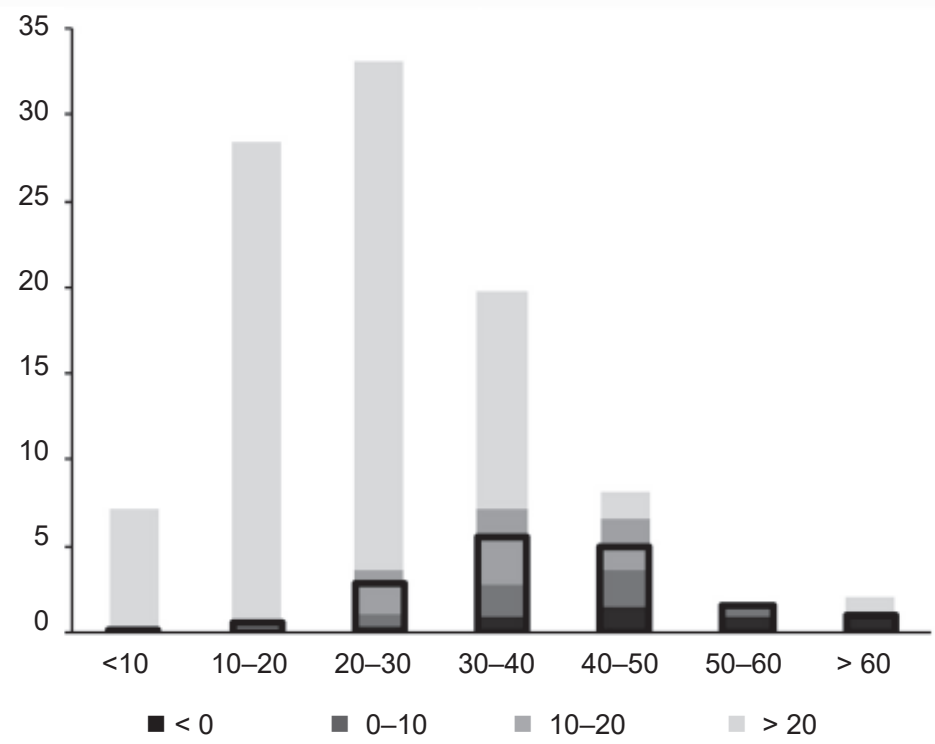

Note: Risky LSTI levels are determined using the financial reserve under stress for individual new loans reported in the Survey. Risky LSTI levels are those for which a significant proportion of new loans have a reserve below the threshold. Those loans are indicated with a frame.

Source: Czech National Bank data, authors' calculations 


\section{Figure 4: Distribution of loans by LTI and ratio of the loan provided to the hypothetically repayable loan under stress}

(x-axis: DTI in \%; y-axis: share of loans in \%; ratio in \%; 2017 H2)

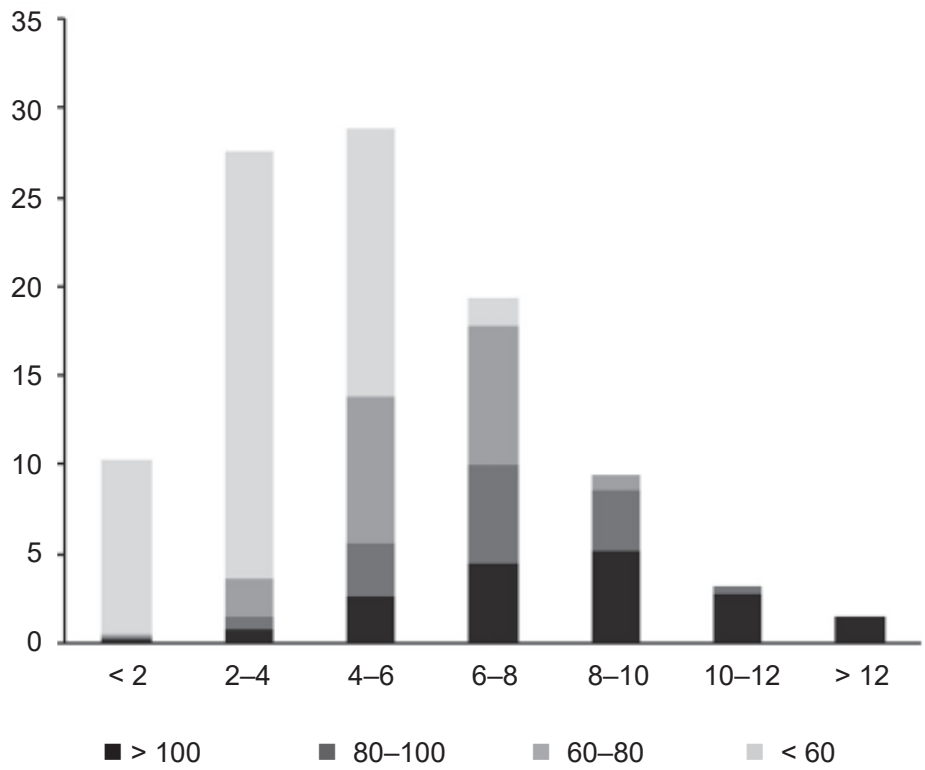

Note: Risky LTI levels are determined using the hypothetically repayable loan under stress (the loan size with the longest permissible maturity and the highest permissible ratio of instalments to income) for individual new loans reported in the Survey, which is compared with the actual loan size. Risky LTI levels are those for which a significant proportion of new loans exceed the hypothetically repayable level.

Source: Czech National Bank data, authors' calculations

Figure 3 displays the results of stress testing of the individual new loans provided in the second half of 2017 from the perspective of the borrowers' ability to service these loans continuously in accordance with their repayment schedule. As $F R_{T H}$, we consider $10 \%$ of net income, which is roughly the average long-term household saving rate observed in the Czech Republic, or CZK 5,000 (roughly 10\% of the average income documented by applicants for new loans according to the survey). The share of individual loans with excessive debt service (i.e., with $F R_{S}$ below this $F R_{T H}$ ) prevails around LSTI equal to $40 \%$. We therefore consider this LSTI level relatively more risky.

Figure 4 displays the results of stress testing of the individual new loans provided in the second half of 2017 from the perspective of the borrowers' ability to repay these 
loans in full over their remaining period of economic activity (i.e., even after the loan has been restructured and the repayment schedule changed). The share of individual loans of excessive size (i.e., for which $L / H R L_{S}>100 \%$ ) prevails around LTI equal to 8 . We therefore consider this LTI level relatively more risky.

The data for the first quarter of 2017 can also be used to demonstrate that simultaneous use of more borrower-based measures may lead to higher efficiency of the individual measures but not necessarily to additional restrictions on the total volume of new loans provided (compared to a situation where only one of the measures would be in place). In the first quarter of 2017, the potential overvaluation of house prices equals 15\% (Figure 2), suggesting that an LTV limit at around $80 \%$ could be considered for the next period. At the same time, $30 \%$ of new loans were provided with an LTV above $80 \%$ and $13 \%$ of new loans with an LTI above 8 or LSTI above $40 \%$ ( $7 \%$ of new loans having LTV above $80 \%$ at the same time).

If the LTV limit was set as a hard limit at $90 \%$ and a soft limit at $80 \%$, allowing $15 \%$ of new loans to be provided with LTV above $80 \%$, lenders would have to reduce the provision of new loans with LTV over $80 \%$ by 15 pp in order to meet the LTV limits in the next period. If complementary LTI and LSTI limits were set at 8 and $40 \%$ respectively, allowing $5 \%$ of new loans to breach these limits, lenders would probably react as follows: They would first restrict new loans with LTV above $80 \%$ and - at the same time - LTI above 8 or DSTI above $40 \%$. By doing this, they would be closer to satisfying each of the individual limits by $7 \mathrm{pp}$. The permitted 5\% of new loans with LTI over 8 or LSTI over $40 \%$ would roughly cover the remaining $8 \%$ of the volume of such loans that have LTV below $80 \%$ and are therefore not restricted by the LTV limit. Such a combination of measures would therefore lead to eliminating new loans with riskier LTV as well as LTI or LSTI values, while not resulting in higher restriction on the total volume of new loans compared to the single LTV limit.

\section{Conclusion}

Although the use of residential real estate macroprudential tools has become common in recent years, rigorous approaches to their calibration have been relatively scarce. In this paper, we presented an approach to measuring direct risks to financial stability related to residential real estate exposures and to calibrating borrower-based macroprudential measures with the aim of limiting these risks. To this purpose, we concentrated on direct risks to financial stability that are associated with residential real estate exposures and abstract from indirect risks that can be related to a sharp fall in household consumption caused by over-indebtedness of households. 
First, we suggested to asses risks associated with residential real estate exposures using the degree of overvaluation of house prices, the level of credit standards and the volume of new loans. Overvalued prices and relaxed credit standards are indicators of the riskiness of new loans. Together with the volume of new loans, they indicate the total size of the risks associated with the provision of new loans. In this vein, we defined a macroprudential indicator of potential losses on new loans, which should - due to the prudent assumption used when constructing this indicator - be taken as an indicator of such losses for macroprudential purposes. A rise in the MIPL over time indicates growth in risks, to which it may be appropriate to respond with macroprudential policy. The evolution of the components of this indicator can meanwhile help determine which macroprudential instrument to use. A fall in the MIPL following the introduction of macroprudential instruments can also indicate the degree of effectiveness of the instruments.

In order to calibrate the LTV ratio, we suggested monitoring the overvaluation of house prices: The level of the house price overvaluation determines the rate of overcollateralization which is needed to overcome credit losses in case of the loan default in a pre-emptive manner. To calibrate the DTI and DSTI limits, we proposed a stress test of individual new mortgage loans. First, we identified individual new loans with excessive debt service using a concept of financial reserve under stress. As risky DSTI levels, we suggested to consider those for which the share of individual loans with excessive debt service significantly increases. Then, we identified individual new loans of excessive debt size using a hypothetical repayable loan under stress. As risky DTI levels, we again suggested to consider those where the share of individual loans with excessive debt service prevail.

We further demonstrated the applicability of this approach on the case of the Czech Republic. To this end, we used anonymized survey-based data on new loans that have been collected by the Czech National Bank since the second half of 2015. We showed that in the second half of 2017, new loans with LTV over $80 \%$, LSTI over $40 \%$ and LTI over 8 could be deemed relatively more risky according to our approach. While our data are loanlevel and allow us to determine the risky levels of the LTI and LSTI ratios, the same values of DSTI and DTI can usually be considered equally or more risky for another borrower with similar income characteristics. For this reason, we suggested to consider the risky DSTI and DTI levels equal to or lower than those determined on the basis of LSTI and LTI data. Finally, we also showed that combining LTV limits with limits on DTI or DSTI - all in the form of a soft limit - can lead to increased efficiency of the individual measures, while not necessarily additionally restricting the total volume of new loans compared to a situation where only one measure would be in place. 


\section{References}

Cassidy, M., Hallissey, N. (2016). The Introduction of Macroprudential Measures for the Irish Mortgage Market. The Economic and Social Review, 47(2), 271-297.

Cerutti, E., Dagher, J., Dell'Ariccia, G. (2015). Housing Finance and Real Estate Booms: A CrossCountry Perspective. International Monetary Fund. Washington, DC Staff Discussion Note No. 2015/12, https://doi.org/10.5089/9781513571393.006

CNB (2018). Financial Stability Report 2017/2018. Prague: Czech National Bank

Dell'Ariccia, G., Rabanal, P., Crowe, C. (2011). Policies for Macrofinancial Stability: Options to Deal with Real Estate Booms. International Monetary Fund. Washington, DC Staff Discussion Notes No. 11/2, https://doi.org/10.5089/9781616350901.006

Dell'Ariccia, G., Igan, D., Laeven, L., et al. (2012). Policies for Macrofinancial Stability: How to Deal with Credit Booms. International Monetary Fund. Washington, DC Staff Discussion Note No. 12/06, https://doi.org/10.5089/9781475504743.006

Dell'Ariccia, G., Igan, D., Laeven, L., et al. (2016). Credit Booms and Macrofinancial Stability. Economic Policy, 31(86), 299-355, https://doi.org/10.1093/epolic/eiw002

ESRB (2013). Recommendation of the European Systemic Risk Board of 4 April 2013 on Intermediate Objectives and Instruments of Macro-Prudential Policy (ESRB/2013/1). Official Journal of the European Union. Available at: https://www.esrb.europa.eu/pub/ pdf/recommendations/ESRB_2013_1.en.pdf?b3291f19e4a37b5bab77b657df7ec97d

ESRB (2014). The ESRB Handbook on Operationalising Macro-Prudential Policy in the Banking Sector. Frankfurt am Main: European Systemic Risk Board, March 2014.

ESRB (2016). Vulnerabilities in the EU Residential Real Estate Sector. Frankfurt am Main: European Systemic Risk Board, November 2016, https://doi.org/10.2849/73346

Fáykiss, P., Palicz, A., Szakács, J., et al. (2018). Experiences of Debt Cap Regulations in Hungarian Retail Lending. Financial and Economic Review, 17(1), 34-61, https://doi.org/10.25201/fer.17.1.3461

Finansinspektionen (2017). Interest Rate Adjustment Periods - An Economic Vulnerability?

Finansinspektionen Analysis No. 9, March 2017. Available at: https://www.fi.se/contentas sets/1dcc1e4d818c4751aeb56d3265ee2e16/fianalys_9_eng.pdf

FPC (2015). The Financial Policy Committee's Powers over Housing Tools. FPC Policy Statement, July 2015.

Geršl (2016). Calibration Issues in Central, Eastern and Southeastern Europe. Lecture at World Bank Workshop on Macroprudential Policymaking in Emerging Europe, Vienna, 2 June 2016.

IMF (2018). Technical Note - Calibration of a Debt Service-to-income Limit in Romania - Evidence from Microdata. International Monetary Fund. Washington, DC Country Report No. 18/161. Jácome, L. I., Mitra, S. (2015). LTV and DTI Limits-going Granular. International Monetary Fund. Washington, DC Working Paper No. 15/154, https://doi.org/10.5089/9781513551449.001 
NBS (2016). Decree of Národná banka Slovenska of 13 December 2016 No 10/2016 Laying Down Detailed Provisions on the Assessment of Borrowers' Ability to Repay Housing Loans, in Force Since 1 January 2017, Národná banka Slovenka. Available at: https://www.nbs. sk/_img/Documents/_Legislativa/_FullWordingsOther/EN_O-10-2016.pdf

O'Brien, M., Ryan, E. (2017). Motivating the Use of Different Macro-prudential Instruments: The Countercyclical Capital Buffer vs. Borrower-Based Measures. Central bank of Ireland, Economic Letter SeriesNo. 2017/15.

Plašil, M., Andrle, M. (2019). Assessing House Price Sustainability. Czech National Bank. Thematic Articles on Financial Stability No. 1/2019. Available at: https://www.cnb.cz/ export/sites/cnb/en/financial-stability/.galleries/thematic-articles-on-financial-stability/ tafs_2019_01_en.pdf

Riksbank (2012). Countercyclical Capital Buffers as a Macroprudential Instrument. Riksbank Studies, December 2012.

Schneider, M. (2013). Are Recent Increases of Residential Property Prices in Vienna and Austria Justified by Fundamentals? Monetary Policy \& the Economy, 4, 29-46.

Thedéen, E. (2018). Financial Stability and Macroprudential Policy. Finansinspektionen, Speech on Meeting of the Standing Committee on Finance, 22 January 2018.

Upper, C. (2017). Macroprudential Frameworks, Implementation and Relationship with Other Policies-Overview. Bank for International Settlements. Basel BIS Paper No. 94. Available at: https://www.bis.org/publ/bppdf/bispap94.pdf 